\title{
The Association Between Conditional Cash Transfer and Fertility Intention in Indonesia
}

\author{
Rafly Parenta Bano ${ }^{1}$, Omas Bulan Samosir ${ }^{2}$, Triasih Djutaharta ${ }^{3}$ \\ ${ }^{1}$ Statistic Merauke Regency, Indonesia (email: rbano@bps.go.id) \\ ${ }^{2}$ The Faculty of Economics and Business, Universitas Indonesia \\ ${ }^{3}$ The Faculty of Economics and Business, Universitas Indonesia
}

\begin{abstract}
This study aims to analyze the relationship between conditional cash transfer (PKH in Indonesia) acceptance status and fertility intentions of married women ages 15-49 years who do not use contraception in Indonesia. The data used in this research comes from the results of SUSENAS 2017. The sample was limited to married women aged 15-49 years not currently using a contraceptive method. Ordinal logistic regression was employed to analyze the relationship between PKH acceptance status and fertility intention after controlling for the effects of individual control factors, while a multilevel ordinal logistic model was used to investigate the effects of contextual factors. The study results showed that after controlling for the effects of individual and contextual variables, a high fertility intention was associated with receiving PKH. Women from PKH beneficiary households tended to maximize the assistance received by increasing the number of children (moral hazard behavior). Moral hazard behavior was more pronounced in women from households that had received PKH or received PKH but could not show their cards.
\end{abstract}

\section{Keywords:}

Program Keluarga Harapan; fertility intentions; multilevel ordinal regression; moral hazard behavior

\section{Introduction}

One factor that causes the fertility rate of poor households to remain high is the provision of cash assistance for poor households. According to Malthus, the mechanism allowed their children to marry earlier and thus give birth to more children to maximize the assistance received (Malthus, 1798). Stecklov et al. (2007) showed that the Programa de Asignación Familiar (PRAF) in Honduras was shown to increase the fertility rate of beneficiary households by 2 to 4 percent. PRAF is health and nutrition assistance for every child under the age of 3 years (without limitation on the number of children), every pregnant woman (maximum 2 people) and educational assistance for every child aged 6-12 years (maximum 3 children) who do not drop out of school before grade 4 . Such assistance makes parents in Honduras tend to maximize assistance by increasing the number of children (moral hazard behavior). The moral hazard behavior of households receiving cash transfers was also detected in Indonesia. Bastanta (2017) shows that beneficiaries of the Family Hope Program $(\mathrm{PKH})$ tend to maximize the PKH assistance received by increasing the number of children in the long term. PKH is expected to affect changes in fertility intention through the improvement in the quality of children through better access to health and education services. The maximum assistance program participants receive will reach the maximum amount if they have 4 or more children. Moral hazard program participants are arrested from households with at least 3 children (Bastanta, 2017). The number of previous children affects a woman's probability of having children again (Arroyo \& Zhang, 1997; Todd, Winters, \& Stecklov, 2012) 
Fertility intentions are formed from three main factors, namely attitudes, subjective norms, and perceived behavioral control (Ajzen \& Klobas, 2013). Attitudes state an evaluation forms within a person regarding the decision to have children and that his decision will have positive or negative consequences for him. Subjective norms are a person's perception of psychological support or pressure from the social environment, such as family or close relatives, regarding their decision to have children. It is called subjective because people need not match their perceptions with other people's opinions or social norms in their environment. Meanwhile, perceived behavioral control refers to a person's perception or belief about the ease or difficulty of having a child. Like subjective norms, perceived behavioral control emphasizes a person's perception or belief about a situation. For example, rich people may feel they cannot afford to have children because of the limited time allocated for raising children. Meanwhile, underprivileged people may believe that they have sufficient control over their finances to have children, regardless of their actual income (Ajzen \& Klobas, 2013).

In developing countries, conditional cash transfers (CCT) aim to break the chain of poverty in the household by increasing the human capital of children from the womb. (Bourguignon, Ferreira, \& Leite, 2003; Dewey \& Begum, 2011; Fiszbein et al., 2009; Leroy, Ruel, Habicht, \& Frongillo, 2014). Thus, the CCT program is a function of the number of children. In Indonesia, CCT is known as the Program Keluarga Harapan (PKH). Based on the Minister of Social Affairs Regulation (Permensos) number 1 of 2018 about PKH, some state that $\mathrm{PKH}$ is a conditional social assistance program for poor/vulnerable families. The targets are low-income families with pregnant/ breastfeeding mothers, children aged 0-6 years, school-age children, elderly people and persons with disabilities (Kementerian Sosial, 2018).
The program is to support the school children age to attend to school and participate, and the vulnerable group to attend health facility regularly. The assistance that families receive depends on the number of those components. Thus, the PKH assistance received is a function of the number of children

This raises concerns that the CCT program will encourage households to have more children (Garganta et al, 2017; Malthus, 1798; Rosenberg et al, 2015; Stecklov et al, 2007). For example, in Honduras, Stecklov et al (2007) show a positive relationship between the CCT program and fertility, with the CCT program causing a 2-4 percent increase in the chance of birth within 2 years. The increased chance of birth is because the assistance will increase when there is an addition of pregnant women or children, resulting in moral hazard from beneficiaries.

Moral hazard behavior from cash transfer recipient households was also detected in Indonesia. Bastanta (2017) shows that the Family Hope Program (PKH) tends to maximize PKH assistance received by increasing the number of children in the long term. The CCT program can also affect fertility through contraceptives and delay teenagers' marriage in beneficiary households (Gulematova, 2011; Stecklov et al, 2007). In Kenya, the CCT program caused delays in sexual intercourse and first pregnancy among people under the age of 25 but did not significantly delay marriage (Handa et al., 2014; Handa et al., 2015). According to Stecklov et al (2007), fertility preferences for the quantity or quality of children are closely related to the size of assistance, and how programs affect the absolute and relative costs of the quantity and quality of children.

This study analyzed the relationship between $\mathrm{PKH}$ cash transfers and fertility intentions for women aged 15-49 years who are not using contraceptives. In some previous studies, the relationship between $\mathrm{PKH}$ assistance and fertility used fertility outcome 
variables, such as birth opportunities (Garganta et al., 2017; Nandi \& Laxminarayan, 2016) and birth spacing (Bastanta, 2017; Todd et al., 2012), then in this study, we used the fertility behavior variable. This is because, to our knowledge, no study uses the fertility intention variable to see its relationship with household status as $\mathrm{PKH}$ assistance recipients. Also, it is essential to carry out studies on fertility intentions because in some countries fertility intention measures are used to help predict fertility rates.

\section{Methods \\ Data and variables}

The data came from SUSENAS, a sociodemographic and economic survey conducted by Statistics Indonesia (Badan Pusat Statistik) annually. In 2017, SUSENAS was implemented in 34 provinces in Indonesia, covering 300,000 households spread across 514 regencies/cities. SUSENAS 2017 uses 3-stage multistage stratified sampling to collect data on the individual and household levels. Multistage sampling is frequently used for household surveys where the population is distributed over a wide area and presents a compound requirement in the selection of the sample, such as attributes detected in the previous stages (Chauvet, 2015; Whittemore, 1997)

The first stage is selecting 25 percent Census Block (BS) by Probability Proportional to Size with the size is the number of households. The second stage is systematically selecting the number of BS according to the allocation in each strata urban/rural per regency/city. The third stage systematically selects 10 households from each BS with implicit stratification according to the education level of the household head as a proxy of household welfare (Badan Pusat Statistik, 2018). SUSENAS 2017 collected information on 297,276 households and $1,132,749$ individuals.

The unit of analysis in this study was married women aged 15-49 years not currently using contraceptive methods. Two reasons underlie the selection of the unit of analysis. First, women who are currently married and not currently using family planning devices have the probability of reproducing and thus having the intention to have children (Miller \& Pasta, 1995). Second, fertility and family planning questions in the 2017 SUSENAS were only asked to evermarried women aged 15-49 years. After filtering out the missing husband's characteristics, 62,179 women were in the final analysis unit.

The dependent variable in this study is fertility intention, namely whether or not you want to have another child/child in the future. The fertility intention variable used an ordinal measurement scale with three categories, namely high intention (wanting to have children $<2$ years) coded 3 , low intention (wanting to have more children $\geq 2$ years) coded 2 and did not have an intention coded 1 (reference). The main independent variable is the status of household $\mathrm{PKH}$ acceptance (PKH), namely whether the household has or has never received $\mathrm{PKH}$ or is currently registered as $\mathrm{PKH}$ recipient. The main independent variable uses a nominal measurement scale with three categories, namely receiving $\mathrm{PKH}$ and being able to show cards (code 2), currently not receiving $\mathrm{PKH}$ or currently receiving $\mathrm{PKH}$ but unable to show card (code 1), and never receiving PKH (code 0). Meanwhile, the independent control variables consist of individual variables and contextual variables. Individual variables include: area of residence (urban), work status (work), level of education of women (educf), level of education of husbands (educm), age of women (agef), age of husbands (agem), internet access (inet), income level (exp_cap), homeownership status (hou). Contextual variables are the economic, social, cultural or demographic conditions or characteristics of an individual's area. Contextual variables include the total fertility rate (TFR), gender empowerment index (IDG), and contraceptive prevalence rate $(\mathrm{CPR})$ of 34 provinces in Indonesia. These 
contextual variables reflect fertility patterns and a woman's ability to make decisions, especially those related to fertility where she lives.

\section{Empirical Strategy}

The analysis methods used in this study were univariate, bivariate, and multivariate analyzes. The multivariate analysis uses ordinal logistic regression analysis and multilevel logistic ordinal because the dependent variable is categorical (no, low, and high), and the variables used in this study are observed at different levels with stratified data structures (Heck, Thomas, \& Tabata, 2010). Ordinal logistic regression was used to analyze the relationship between PKH acceptance status and fertility intention after controlling for individual factors. Meanwhile, a multilevel ordinal logistic model is used when contextual factors are added to the model.

In contrast to multinomial regression, in ordinal regression, the dependent variable categories are ordinal in scale (Hosmer \& Lemeshow, 2000). Suppose there are $p$ independent variables, then the log odds or logit function is as follows:

$\log \frac{P(Y \leq k \mid X)}{P(Y>k \mid X)}=\operatorname{logit} P(Y \leq k \mid X)=\alpha_{k}+\beta_{1} X_{1}+\cdots+\beta_{p} X_{p}$

In the ordinal logit model (proportional odds model), the slope of the independent variables is assumed to be the same, but the intercept is different for all categories of the dependent variable. This differs from the multinomial logit model, where both the intercept and the slope are different for each category of the dependent variable. The value of $\beta 1$ shows that individuals with characteristics $\mathrm{X} 1$ are equal to 1 , the $\log$ odds for experiencing $\mathrm{Y}$ is equal to category 0 or 1 (the lowest) is higher by $\beta 1$ than experiencing $Y$ is equal to category 2 compared to individuals with characteristics $\mathrm{X} 1$ equal to 0 .

In this study, the estimation will be carried out using three models according to groups of women based on parity. The first model estimates the effect of the PKH acceptance status variable on fertility intentions with and without control of other independent variables from the group of women who had 1 child. The second model is also the same but from the group of women who already had 2 children. A third model is a group of women who already had 3 or more children. Separation sub sample in those models to know the different impact of number of children to $\mathrm{PKH}$ acceptance on fertility intention.

Referring to equation (1), the ordinal logit model for each parity group is as follows:

$\log \left[\frac{P(Y \leq k \mid x)}{1-P(Y \leq k \mid x)}\right]=\alpha_{k}+\beta_{1} P K H 1+\beta_{2} P K H 2+\boldsymbol{X}^{T} \boldsymbol{\beta}$

where $P\left(Y_{q r s} \leq k \mid x\right)$ is the cumulative chance of a currently married woman having a fertility intention in the category of less than or equal to category $\mathrm{K}$ where $\mathrm{K}=1,2,3$.

The goodness of fit test of the ordinal logistic regression model were tested by comparing models with or without covariates. This is performed commonly using the likelihood ratio test, which compares the likelihood of the model with independent variables/covariates against the likelihood of the model without covariates. Removing independent variables from a model will almost always make the model fit less well (i.e., a model will have a lower log likelihood), but it is necessary to test whether the observed difference in model fit is statistically significant. Given that $\mathrm{H}_{0}$ holds that the reduced model is true, a p-value for the overall model fit statistic less than 0.05 would compel us to reject the null hypothesis. It would provide evidence against the reduced model in favor of the current model.

The multilevel model is used for stratified data structures where the error at each level is different. The multilevel ordinal regression model analyzes stratified data structures between one ordinal scale dependent variable 
with one or more independent variables with different levels. According to Marquart-Pyatt (2012), there are methodological problems if you do not use multilevel regression models, namely when aggregating individual data to a higher level (province) or disaggregating data at the provincial to the individual level. Aggregating individual-level data to higher levels can eliminate variation at the individual level. Meanwhile, disaggregating the provincial level data to the individual level will violate the independent assumptions in the OLS regression (Snijders \& Bosker, 1999). By using a hierarchical data structure, individuals living in the same province will have the same provincial-level characteristics. Thus, using multilevel regression is the preferred approach because it considers the problem of independent assumptions (Heck et al., 2010; Hox, 2010). If the multilevel model is ignored while still using the OLS regression approach, the standard error will underestimate the significance of the resulting spurious parameter estimates (Hox, 2010).

In this study, there are two levels, where the first level is nested individuals at the second level, namely the province. To describe the two-level data structure model is as follows: Suppose there are $i=1,2, \ldots, n_{i}$ individuals (level 1 units) nested in $j=1,2, \ldots, n$ provinces (level 2 units). Then the ordinal multilevel model at level 1 is:

$$
\begin{aligned}
\log \left[\frac{P\left(Y_{i j} \leq k \mid x\right)}{P\left(Y_{i j}>k \mid x\right)}\right]= & \beta_{0 j}+\beta_{1 j} P K H 1_{i j}+\beta_{2 j} P K H 2_{i j}+ \\
& \sum_{q=3}^{Q} \beta_{i j} X_{i j}+\sum_{k=2}^{K} \alpha_{k}
\end{aligned}
$$

and the models at level 2 are:

$$
\begin{aligned}
\beta_{0 j}= & \gamma_{00}+\gamma_{01} T F R_{j}+\gamma_{02} I D G_{j} \\
& +\gamma_{03} C P R_{j}+u_{0 j}
\end{aligned}
$$

where $u_{0 j}$ is the random effect at level 2. Interpretation of the parameter estimation coefficients is in principle the same as the interpretation in the ordinal logit model.
The goodness of fit of the multilevel ordinal regression models was tested by comparing the residual variation of the model with multilevel with the variation of the residual with the model without multilevel. The test statistic is the intraclass correlation coefficient (ICC). The range of ICC values is between 0 and 1 . If the ICC value equals 0 , fertility intention does not vary at the province level. Estimation using a multilevel regression model is not required. Meanwhile, if the ICC value equals 1, it means there is no difference in fertility intention between individuals at the provincial level or the variation in fertility intention of women is only explained by variation at the province level. There is no agreement on the minimum threshold for the ICC value considered sufficient to perform multilevel regression. In its application, the ICC value is usually very small. Even though it is very small, if it is ignored by not modeling with multilevel regression, it can lead to serious problems, namely making Type-I errors (Arceneaux \& Nickerson, 2009; Huang, 2016; Musca et al., 2011).

\section{Results}

The results of the univariate analysis showed that around 44.8 percent of women aged 15-49 years in Indonesia stated that they intend to have children in the future, and 55.2 percent stated that they did not intend to have children (Table 1). Of those who stated that they intended to have children, 17.4 percent stated that they intend to have children in the next 2 years (low intention). Meanwhile, the percentage of those who stated that they intend to have children in less than 2 years (high intention) was 27.3 percent.

The percentage of women aged 1549 years from households receiving $\mathrm{PKH}$ benefits is 7.0 percent. Meanwhile, women from households that did not receive $\mathrm{PKH}$ benefits were as much as 93.0 percent. From the percentage of 7.0 percent, women who received PKH benefits, as much as 2.6 percent were women who came from households that 
had received PKH (currently do not receive $\mathrm{PKH}$ ) or who receive $\mathrm{PKH}$ but cannot show their cards, and in the amount of 4.4 percent are women from households currently receiving PKH but can show a card.

The results of the bivariate analysis on the percentage of fertility intention according to background characteristics are presented in Table 2. It can be seen that the percentage of women who intend to have children from household groups that receive $\mathrm{PKH}$ is relatively lower than the percentage of women who intend to have children from household groups that do not receive $\mathrm{PKH}$. It can also be seen that for women aged 15-49 who are married and PKH recipient households, almost 20 percent or

Table 1.

Frequency Distribution of Research sample: Indonesia SUSENAS 2017

\begin{tabular}{|c|c|c|c|}
\hline \multirow{2}{*}{\multicolumn{2}{|c|}{ Research variable }} & \multicolumn{2}{|c|}{ Women aged $15-49$ years } \\
\hline & & Percentage / Mean & SD \\
\hline \multicolumn{2}{|c|}{$(1)$} & $(2)$ & (3) \\
\hline \multirow{3}{*}{ Fertility intentions } & Not & 55.2 & \\
\hline & Low & 17.4 & \\
\hline & High & 27.3 & \\
\hline \multirow{3}{*}{ PKH status } & Never received $\mathrm{PKH}$ & 93.0 & \\
\hline & $\begin{array}{l}\text { Have received PKH or currently } \\
\text { receive PKH but cannot show a card }\end{array}$ & 2.6 & \\
\hline & $\begin{array}{l}\text { Currently accepts PKH and can } \\
\text { show cards }\end{array}$ & 4.4 & \\
\hline \multirow{3}{*}{ Women age } & $15-24$ years & 4.0 & \\
\hline & $25-29$ years & 11.5 & \\
\hline & $30-49$ years & 84.5 & \\
\hline \multirow{3}{*}{ Husband's age } & $\leq 24$ years & 1.0 & \\
\hline & $25-29$ years & 5.6 & \\
\hline & $\geq 30$ years & 93.3 & \\
\hline \multirow{2}{*}{ Residence } & Village & 56.7 & \\
\hline & City & 43.3 & \\
\hline \multirow{3}{*}{ Number of children born alive } & 1 child & 26.3 & \\
\hline & Two children & 30.7 & \\
\hline & 3 or more children & 42.9 & \\
\hline \multirow{3}{*}{ Women's education } & Low $(\leq \mathrm{SD})$ & 44.6 & \\
\hline & Intermediate (SMP-SMA) & 44.3 & \\
\hline & Height (PT) & 11.0 & \\
\hline \multirow{3}{*}{ Husband's education } & Low $(\leq \mathrm{SD})$ & 41.8 & \\
\hline & Intermediate (SMP-SMA) & 47.4 & \\
\hline & Height (PT) & 10.7 & \\
\hline \multirow{3}{*}{ Working status } & Does not work & 44.5 & \\
\hline & Informal & 38.7 & \\
\hline & Formal & 16.9 & \\
\hline \multirow{2}{*}{ Income level (rupiah) } & $\leq$ Poverty Line (Rp. 374,478, -) & 10.7 & \\
\hline & > Poverty Line (Rp. 374,478, -) & 89.3 & \\
\hline \multirow{2}{*}{ Owned house ownership } & Do not have yet & 21.6 & \\
\hline & Have & 78.4 & \\
\hline \multirow{2}{*}{ Internet access } & Never & 76.7 & \\
\hline & Ever & 23.3 & \\
\hline Total Fertility Rate (TFR) & & 2.31 & 0.25 \\
\hline (Gender Empowerment Index/GDI) & & 68.35 & 607 \\
\hline Contraceptive Prevalence Rate (CPR) & & 52.50 & 9.34 \\
\hline
\end{tabular}

Source: SUSENAS 2017 (Authors' compilation). 
Table 2.

Percentage of women according to household PKH acceptance status and fertility intention: Indonesia SUSENAS 2017

\begin{tabular}{|c|c|c|c|c|}
\hline \multirow{2}{*}{ PKH acceptance status, parity, and education level } & \multicolumn{3}{|c|}{ Fertility intentions } & \multirow{2}{*}{ Total } \\
\hline & Not & Low & High & \\
\hline$(1)$ & $(2)$ & (3) & $(4)$ & $(5)$ \\
\hline \multicolumn{5}{|l|}{ PKH acceptance status } \\
\hline Never received $\mathrm{PKH}$ & 54.5 & 17.6 & 27.9 & 100.0 \\
\hline Ever received or currently accepted but unable to show card & 65.3 & 13.8 & 20.9 & 100.0 \\
\hline Currently accepts and can show cards & 65.0 & 15.9 & 19.1 & 100.0 \\
\hline \multicolumn{5}{|l|}{ Never received PKH } \\
\hline Has 1 child & 20.8 & 21.7 & 57.5 & 100.0 \\
\hline Has 2 children & 55.0 & 20.6 & 24.4 & 100.0 \\
\hline Have $3+$ children & 76.9 & 12.5 & 10.6 & 100.0 \\
\hline \multicolumn{5}{|l|}{ Ever received or currently accepted but unable to show card } \\
\hline Has 1 child & 23.0 & 15.5 & 61.5 & 100.0 \\
\hline Has 2 children & 50.6 & 17.4 & 32.0 & 100.0 \\
\hline Have $3+$ children & 75.2 & 12.6 & 12.2 & 100.0 \\
\hline \multicolumn{5}{|l|}{ Currently accepts and can show cards } \\
\hline Has 1 child & 18.4 & 21.2 & 60.4 & 100.0 \\
\hline Has 2 children & 51.3 & 17.8 & 31.0 & 100.0 \\
\hline Have $3+$ children & 74.6 & 14.7 & 10.7 & 100.0 \\
\hline
\end{tabular}

Source: SUSENAS 2017 (Authors' compilation).

1 in 5 people say they intend to have children in less than 2 years (high fertility intention). Percentage of women from households that have received $\mathrm{PKH}$ (currently not receiving PKH) or who receive PKH but cannot show cards that have a high fertility intention of 20.9 percent, or the tendency is higher than that of women from households currently receiving PKH and being able to show a card. Meanwhile, about 15 percent answered that they intended to have children, but within over 2 years.

Before controlling for the influence of the other independent variables, women from households that had or currently received $\mathrm{PKH}$ were more likely to intend not to have children than women from households that had never received PKH. Women who have received $\mathrm{PKH}$ (currently do not receive) or currently receive $\mathrm{PKH}$ but cannot show a card are approximately 1.57 times more likely to intend not to have children than women who have never received PKH. Likewise, women who currently receive PKH and can show a card are about 1.55 times more likely to intend not to have children than women who have never received PKH. Meanwhile, women who have never received $\mathrm{PKH}$ are around 1.47 times and about 1.64 times more likely to intend to have high fertility intentions when compared to women from households who had received PKH (currently not receiving) or currently receive $\mathrm{PKH}$ but cannot show a card or households that currently receive $\mathrm{PKH}$ and can show cards.

However, after interacting with or controlling with the women's parity variable, women from households that had or currently received PKH had a higher tendency to have high fertility intentions than women from households that had never received PKH. For example, women who have had 1 child and come from a household that has received PKH (currently not receiving it) or currently receive PKH but cannot show a card are 1.18 times more likely to have high fertility intentions than women who come from households that have never received PKH. 
Table 3.

Estimation of the effect of PKH acceptance status on fertility intention according to women's parity: Indonesia SUSENAS 2017

\begin{tabular}{|c|c|c|c|c|}
\hline $\begin{array}{l}\text { Independent } \\
\text { variable }\end{array}$ & $\begin{array}{c}\text { Model I } \\
\text { (parity> } 1 \text { child) } \\
n=62,179\end{array}$ & $\begin{array}{c}\text { Model II (parity of } 1 \\
\text { child) } \\
n=16,383\end{array}$ & $\begin{array}{c}\text { Model III (parity of } 2 \\
\text { children) } \\
\mathrm{n}=19,099\end{array}$ & $\begin{array}{c}\text { Model IV (parity of } 3 \\
\text { children) } \\
n=26,697\end{array}$ \\
\hline$(1)$ & $(2)$ & (3) & (4) & $(5)$ \\
\hline PKH1 & $0.152^{* * *}$ & 0.242 & 0.250 ** & 0.0734 \\
\hline 1011 & $(0.0553)$ & $(0.162)$ & $(0.111)$ & $(0.0710)$ \\
\hline РKH2 & $0.157^{* * *}$ & 0.213 * & $0.239^{* * *}$ & $0.101 *$ \\
\hline INAL & $(0.0433)$ & $(0.127)$ & $(0.0882)$ & $(0.0552)$ \\
\hline parity1 & $\begin{array}{c}-1.355^{* * *} \\
(0.0218)\end{array}$ & & & \\
\hline parity2 & $\begin{array}{c}-2.295^{* * *} \\
(0.0237)\end{array}$ & & & \\
\hline educf1 & $\begin{array}{c}0.157^{* * *} \\
(0.0216)\end{array}$ & $\begin{array}{c}0.352^{* * *} \\
(0.0390)\end{array}$ & $\begin{array}{c}0.0893 * * \\
(0.0368)\end{array}$ & $\begin{array}{c}0.0762 * * \\
(0.0368)\end{array}$ \\
\hline educf2 & $\begin{array}{l}0.272 * * * \\
(0.0393)\end{array}$ & $\begin{array}{l}0.275^{* * *} \\
(0.0663)\end{array}$ & $\begin{array}{l}0.266^{* * *} \\
(0.0639)\end{array}$ & $\begin{array}{l}0.416^{* * *} \\
(0.0787)\end{array}$ \\
\hline educm 1 & $\begin{array}{c}0.0808^{* * *} \\
(0.0213)\end{array}$ & $\begin{array}{l}0.112^{* * *} \\
(0.0387)\end{array}$ & $\begin{array}{c}0.0814^{* *} \\
(0.0365)\end{array}$ & $\begin{array}{c}0.0816^{* *} \\
(0.0360)\end{array}$ \\
\hline educm 2 & $\begin{array}{c}0.0155 \\
(0.0372)\end{array}$ & $\begin{array}{l}-0.00425 \\
(0.0656)\end{array}$ & $\begin{array}{c}0.0320 \\
(0.0608)\end{array}$ & $\begin{array}{c}0.0595 \\
(0.0698)\end{array}$ \\
\hline agef1 & $\begin{array}{l}0.339^{* * *} \\
(0.0479)\end{array}$ & $\begin{array}{l}0.282^{* * *} \\
(0.0586)\end{array}$ & $\begin{array}{c}0.0950 \\
(0.0888)\end{array}$ & $\begin{array}{l}0.0291 \\
(0.169)\end{array}$ \\
\hline agef2 & $\begin{array}{c}-0.448^{* * *} \\
(0.0480)\end{array}$ & $\begin{array}{c}-0.289 * * * \\
(0.0599)\end{array}$ & $\begin{array}{c}-0.651^{* * *} \\
(0.0880)\end{array}$ & $\begin{array}{c}-1.285^{* * *} \\
(0.166)\end{array}$ \\
\hline agem1 & $\begin{array}{l}0.325^{* * *} \\
(0.0823)\end{array}$ & $\begin{array}{l}0.264^{* * *} \\
(0.0936)\end{array}$ & $\begin{array}{l}0.0169 \\
(0.171)\end{array}$ & $\begin{array}{c}0.143 \\
(0.363)\end{array}$ \\
\hline agem2 & $\begin{array}{l}0.307^{* * *} \\
(0.0820)\end{array}$ & $\begin{array}{l}0.390^{* * *} \\
(0.0943)\end{array}$ & $\begin{array}{l}-0.193 \\
(0.169)\end{array}$ & $\begin{array}{l}-0.322 \\
(0.357)\end{array}$ \\
\hline work1 & $\begin{array}{l}-0.00305 \\
(0.0192)\end{array}$ & $\begin{array}{c}0.0712 * * \\
(0.0363)\end{array}$ & $\begin{array}{l}-0.0236 \\
(0.0325)\end{array}$ & $\begin{array}{l}-0.0424 \\
(0.0317)\end{array}$ \\
\hline work2 & $\begin{array}{l}-0.0323 \\
(0.0269)\end{array}$ & $\begin{array}{l}0.146^{* * *} \\
(0.0448)\end{array}$ & $\begin{array}{c}-0.0998^{* *} \\
(0.0440)\end{array}$ & $\begin{array}{c}-0.213 * * * \\
(0.0560)\end{array}$ \\
\hline urban & $\begin{array}{c}-0.566^{* * *} \\
(0.0197)\end{array}$ & $\begin{array}{c}-0.314^{* * *} \\
(0.0352)\end{array}$ & $\begin{array}{c}-0.647^{* * *} \\
(0.0325)\end{array}$ & $\begin{array}{c}-0.720 * * * \\
(0.0362)\end{array}$ \\
\hline inet & $\begin{array}{l}0.313^{* * *} \\
(0.0255)\end{array}$ & $\begin{array}{l}0.260 * * * \\
(0.0416)\end{array}$ & $\begin{array}{l}0.332 * * * \\
(0.0409)\end{array}$ & $\begin{array}{l}0.364^{* * *} \\
(0.0545)\end{array}$ \\
\hline hou & $\begin{array}{c}-0.119 * * * \\
(0.0212)\end{array}$ & $\begin{array}{c}0.0303 \\
(0.0356)\end{array}$ & $\begin{array}{c}-0.189 * * * \\
(0.0348)\end{array}$ & $\begin{array}{c}-0.194^{* * *} \\
(0.0409)\end{array}$ \\
\hline exp_cap & $\begin{array}{c}-9.25 \mathrm{e}-08^{* * *} \\
(1.13 \mathrm{e}-08)\end{array}$ & $\begin{array}{c}-5.12 \mathrm{e}-08^{* * *} \\
(1.78 \mathrm{e}-08)\end{array}$ & $\begin{array}{c}-1.10 \mathrm{e}-07^{* * *} \\
(1.87 \mathrm{e}-08)\end{array}$ & $\begin{array}{c}-1.52 \mathrm{e}-07^{* * *} \\
(2.63 \mathrm{e}-08)\end{array}$ \\
\hline Threshold 1 & $\begin{array}{c}-1.412 * * * \\
(0.0758)\end{array}$ & $\begin{array}{c}-0.877^{* * *} \\
(0.0888)\end{array}$ & $\begin{array}{c}-0.885^{* * *} \\
(0.161)\end{array}$ & $\begin{array}{c}-0.745^{* *} \\
(0.352)\end{array}$ \\
\hline Threshold 2 & $\begin{array}{c}-0.419 * * * \\
(0.0755)\end{array}$ & $\begin{array}{l}0.183 * * \\
(0.0884)\end{array}$ & $\begin{array}{l}0.0846 \\
(0.161)\end{array}$ & $\begin{array}{c}0.231 \\
(0.352) \\
\end{array}$ \\
\hline
\end{tabular}

Standard errors in brackets; ${ }^{* * *} p<0.01,{ }^{* *} p<0.05,{ }^{*} p<0.1$

Source: SUSENAS 2017 (Authors' compilation). 
Likewise, women who already have 1 child and come from households that currently receive $\mathrm{PKH}$ and can show a card are more likely to be 1,13 times higher fertility intentions than women from households that never received $\mathrm{PKH}$. On the other hand, women from households that never received $\mathrm{PKH}$, if viewed according to each parity group, were more likely to have no children than women from households that received PKH. Thus, there is a tendency or fertility preference for women who receive PKH to increase the number of children (child quantity preference) are more likely to be childless than women from households receiving PKH. Thus, there is a tendency or fertility preference for women who receive $\mathrm{PKH}$ to increase the number of children (child quantity preference) are more likely to be childless than women from households receiving $\mathrm{PKH}$. Thus, there is a tendency or fertility preference for women who receive $\mathrm{PKH}$ to increase the number of children (child quantity preference).

The multivariate analysis of the determinants of fertility intention are presented in Table 3. In model I, after controlling for the number of children and demographic, socioeconomic characteristics, PKH acceptance status has a positive effect on the fertility intention of women aged 15-49 years who are currently married. Women from households currently receiving $\mathrm{PKH}$ and can show a $\mathrm{PKH}$ card are 1.17 times more likely to have a high fertility intention (than have a low fertility intention or have no fertility intention) than women from a household who never received PKH. Besides, women who come from households currently not receiving PKH or are currently receiving $\mathrm{PKH}$ but cannot show a $\mathrm{PKH}$ card are 1.16 times more likely to have high fertility intentions (than have low fertility intentions or have no intention of fertility) compared to women who come from households that have never received $\mathrm{PKH}$.

In model II, after controlling for other independent variables, PKH acceptance status positively affects the fertility intention of women aged 15-49 years who are married and already have 1 child. However, there is no significant relationship between the status of households that have never received $\mathrm{PKH}$ or currently receive PKH but cannot show a card with women's fertility intentions. Meanwhile, the relationship between the status of households that currently receive $\mathrm{PKH}$ and showing a card with a significant fertility intention is at the 10 percent level. Women who have had 1 child and come from households currently receiving $\mathrm{PKH}$ and can show a $\mathrm{PKH}$ card are 1.24 times more likely to have a high fertility intention (than to have a low fertility intention or have no fertility intention) than women from households that have never received $\mathrm{PKH}$.

In model III, after controlling for other independent variables, $\mathrm{PKH}$ acceptance status positively affects the fertility intention of women aged 15-49 years who are married and already have 2 children. Women who have had 2 children and come from households currently receiving $\mathrm{PKH}$ and can show a PKH card are 1.27 times more likely to have a high fertility intention (rather than have a low fertility intention or have no fertility intention) than women from households that have never received PKH. Besides, women with 2 children and came from households that did not currently receive PKH or were currently receiving $\mathrm{PKH}$ but could not show a PKH card were 1.28 times more likely to have a high fertility intention low or no fertility intention) compared to women who come from households that have never received PKH.

In model IV, after controlling for other independent variables, $\mathrm{PKH}$ acceptance status positively affects the fertility intention of women aged 15-49 years who are married and have at least 3 children. However, there is no significant relationship between the status of households that have never received PKH or currently receive PKH but cannot 
show a card with women's fertility intentions. Meanwhile, the relationship between the status of households that currently receive PKH and showing a card with a significant fertility intention is at the 10 percent level. Women who have had at least 3 children and come from households currently receiving $\mathrm{PKH}$ and can show a PKH card are 1.11 times more likely to have a high fertility intention (than to have a low fertility intention or no fertility intention) compared to women who come from households that have never received PKH.

The probability of fertility intention according to $\mathrm{PKH}$ acceptance status and women's parity group can be shown in Table 4. Three things are importantly related to the probability of fertility intention if the other independent control variables are in the at means condition. First, the higher the number of children who have had, the chances of a woman having a high fertility intention decrease, or conversely, her chance not to have an increased fertility intention. For example, the chance for a woman with 1 child from a household that currently receives $\mathrm{PKH}$ and has a card to have a high fertility intention is 0.622 , while those who have had 3 or more children are 0.105 . Second, in all women's parity groups, the chance of not having a fertility intention was higher for women who came from households that had never received PKH. Third, the probability of having 1-2 children to have a high fertility intention is higher for women who come from households that have received PKH or are currently receiving PKH but cannot show their cards.

Multilevel regression was used to determine how the influence of the variable PKH acceptance status on the fertility intention of married women aged 15-49 years when also controlled by contextual factors. Some results of previous studies indicate that variations in fertility intentions of currently married women aged 1549 years are also explained by variations in the provincial level independent variables. (McGuire \& Stephenson, 2015; Phan, 2013).

The magnitude of the variation in fertility intention explained by the variation in the

Table 4.

Probability of women fertility intention according to $\mathrm{PKH}$ acceptance status: Indonesia SUSENAS 2017

\begin{tabular}{|c|c|c|c|}
\hline \multirow{2}{*}{ Parity and PKH acceptance status } & \multicolumn{3}{|c|}{ Fertility intentions } \\
\hline & Not & Low & High \\
\hline$(1)$ & $(2)$ & (3) & $(4)$ \\
\hline \multicolumn{4}{|l|}{ Parity (> 1 child) } \\
\hline Never received PKH & 0.563 & 0.214 & 0.223 \\
\hline Ever received or currently accepted but unable to show card & 0.526 & 0.224 & 0.250 \\
\hline Currently accepts and can show cards & 0.525 & 0.224 & 0.251 \\
\hline \multicolumn{4}{|l|}{ Parity (1 child) } \\
\hline Never received $\mathrm{PKH}$ & 0.206 & 0.223 & 0.571 \\
\hline Ever received or currently accepted but unable to show card & 0.169 & 0.201 & 0.629 \\
\hline Currently accepts and can show cards & 0.174 & 0.204 & 0.622 \\
\hline \multicolumn{4}{|l|}{ Parity (2 children) } \\
\hline Never received PKH & 0.559 & 0.210 & 0.229 \\
\hline Ever received or currently accepted but unable to show card & 0.497 & 0.226 & 0.277 \\
\hline Currently accepts and can show cards & 0.500 & 0.225 & 0.275 \\
\hline \multicolumn{4}{|l|}{ Parity (minimum 3 children) } \\
\hline Never received $\mathrm{PKH}$ & 0.780 & 0.124 & 0.096 \\
\hline Ever received or currently accepted but unable to show card & 0.767 & 0.130 & 0.102 \\
\hline Currently accepts and can show cards & 0.762 & 0.132 & 0.105 \\
\hline
\end{tabular}

Source: SUSENAS 2017 (Authors' compilation). 
provincial level independent variables for the second, third, fourth, and fifth models are respectively 4.00 percent, 3.4 percent, 7.5 percent, and 5.8 percent. As described in chapter 3, this study uses provincial-level independent variables, namely TFR, IDG, and provincial CPR. The multilevel ordinal regression estimation results are as shown in Table 5.
Based on Table 5, after controlling for contextual level variables, the model without multilevel shows that the coefficient of the $\mathrm{PKH}$ acceptance status variable is lower when compared to the model before it is controlled by additional contextual factors. Meanwhile, with the multilevel model, the coefficient of the PKH acceptance status variable is higher than the non-multilevel model. The positive coefficient

Table 5.

Estimation of the effect of PKH acceptance status on fertility intention according to women's parity: Indonesia SUSENAS 2017

\begin{tabular}{|c|c|c|c|c|c|}
\hline \multirow[b]{2}{*}{$\begin{array}{c}\text { Independent } \\
\text { variable }\end{array}$} & $\begin{array}{l}\text { Without } \\
\text { multilevel }\end{array}$ & \multicolumn{4}{|c|}{ With multilevel } \\
\hline & $\begin{array}{c}\text { Model I (parity> } \\
1 \text { child) }\end{array}$ & $\begin{array}{l}\text { Model II (parity> } \\
1 \text { child) }\end{array}$ & $\begin{array}{l}\text { Model III (parity } \\
\text { of } 1 \text { child) }\end{array}$ & $\begin{array}{l}\text { Model IV (parity } \\
\text { of } 2 \text { children) }\end{array}$ & $\begin{array}{c}\text { Model V (parity } \\
\text { of } 3 \text { children) }\end{array}$ \\
\hline (1) & (2) & (3) & (4) & (5) & (6) \\
\hline \multirow{2}{*}{ PKH1 } & $0.133^{* *}$ & $0.161^{* * *}$ & 0.260 & $0.302 * * *$ & 0.0892 \\
\hline & $(0.0555)$ & $(0.0557)$ & $(0.163)$ & $(0.113)$ & $(0.0723)$ \\
\hline \multirow{2}{*}{ PKH2 } & $0.145^{* * *}$ & $0.158^{* * *}$ & 0.181 & $0.307^{* * *}$ & $0.122^{* *}$ \\
\hline & $(0.0434)$ & $(0.0439)$ & $(0.128)$ & $(0.0908)$ & $(0.0565)$ \\
\hline \multirow{2}{*}{ parity1 } & $-1.394^{* * *}$ & $-1.413^{* * *}$ & & & \\
\hline & $(0.0219)$ & $(0.0221)$ & & & \\
\hline \multirow{2}{*}{ parity 2} & $-2.409 * * *$ & $-2.449 * * *$ & & & \\
\hline & $(0.0245)$ & $(0.0248)$ & & & \\
\hline \multirow{2}{*}{ educf1 } & $0.150^{* * *}$ & $0.147^{* * *}$ & $0.308^{* * *}$ & 0.0589 & $0.0796^{* *}$ \\
\hline & $(0.0216)$ & $(0.0219)$ & $(0.0398)$ & $(0.0376)$ & $(0.0375)$ \\
\hline \multirow{2}{*}{ educf2 } & $0.204^{* * *}$ & $0.178^{* * *}$ & $0.200^{* * *}$ & $0.124^{*}$ & $0.352 * * *$ \\
\hline & $(0.0396)$ & $(0.0400)$ & $(0.0676)$ & $(0.0655)$ & $(0.0797)$ \\
\hline \multirow{2}{*}{ educm1 } & $0.0738^{* * *}$ & $0.0648^{* * *}$ & $0.106^{* * *}$ & 0.0481 & 0.0576 \\
\hline & $(0.0214)$ & $(0.0215)$ & $(0.0390)$ & $(0.0370)$ & $(0.0364)$ \\
\hline \multirow{2}{*}{ educm2 } & -0.00291 & -0.0179 & -0.000147 & -0.00331 & -0.00424 \\
\hline & $(0.0374)$ & $(0.0375)$ & $(0.0661)$ & $(0.0617)$ & $(0.0701)$ \\
\hline \multirow{2}{*}{ agef1 } & $0.358^{* * *}$ & $0.368^{* * *}$ & $0.298^{* * *}$ & 0.110 & 0.0173 \\
\hline & $(0.0480)$ & $(0.0482)$ & $(0.0591)$ & $(0.0895)$ & $(0.170)$ \\
\hline \multirow{2}{*}{ agef2 } & $-0.387^{* * *}$ & $-0.373^{* * *}$ & $-0.274^{* * *}$ & $-0.534^{* * *}$ & $-1.227^{* * *}$ \\
\hline & $(0.0481)$ & $(0.0484)$ & $(0.0605)$ & $(0.0889)$ & $(0.168)$ \\
\hline \multirow{2}{*}{ agem1 } & $0.342^{* * *}$ & $0.344^{* * *}$ & $0.252^{* * *}$ & 0.00877 & 0.209 \\
\hline & $(0.0824)$ & $(0.0826)$ & $(0.0944)$ & $(0.172)$ & $(0.363)$ \\
\hline \multirow{2}{*}{ agem2 } & $0.355^{* * *}$ & $0.353^{* * *}$ & $0.372^{* * *}$ & -0.181 & -0.191 \\
\hline & $(0.0823)$ & $(0.0825)$ & $(0.0953)$ & $(0.170)$ & (0.357) \\
\hline \multirow{2}{*}{ work1 } & -0.0358 * & -0.00538 & $0.105^{* * *}$ & -0.0164 & $-0.0577^{*}$ \\
\hline & $(0.0194)$ & $(0.0197)$ & $(0.0372)$ & $(0.0335)$ & $(0.0328)$ \\
\hline \multirow{2}{*}{ work2 } & -0.0216 & -0.00757 & $0.149^{* * *}$ & -0.0517 & $-0.199 * * *$ \\
\hline & $(0.0270)$ & $(0.0272)$ & $(0.0452)$ & $(0.0451)$ & $(0.0573)$ \\
\hline \multirow{2}{*}{ urban } & $-0.473^{* * *}$ & $-0.457^{* * *}$ & $-0.281^{* * *}$ & $-0.488^{* * *}$ & $-0.575^{* * *}$ \\
\hline & $(0.0202)$ & $(0.0206)$ & $(0.0368)$ & $(0.0343)$ & $(0.0379)$ \\
\hline
\end{tabular}




\begin{tabular}{lccccc}
\hline inet & $0.353^{* * *}$ & $0.380^{* * *}$ & $0.282^{* * * *}$ & $0.415^{* * * *}$ & $0.439^{* * *}$ \\
& $(0.0256)$ & $(0.0258)$ & $(0.0422)$ & $(0.0418)$ & $(0.0552)$ \\
hou & $-0.0857^{* * *}$ & $-0.105^{* * *}$ & 0.0350 & $-0.125^{* * *}$ & $-0.238^{* * *}$ \\
& $(0.0214)$ & $(0.0218)$ & $(0.0364)$ & $(0.0360)$ & $(0.0420)$ \\
exp_cap & $-8.88 \mathrm{e}-08^{* * *}$ & $-9.20 \mathrm{e}-08^{* * *}$ & $-4.36 \mathrm{e}-08^{* *}$ & $-1.16 \mathrm{e}-07^{* * *}$ & $-1.30 \mathrm{e}-07^{* * *}$ \\
& $(1.14 \mathrm{e}-08)$ & $(1.16 \mathrm{e}-08)$ & $(1.81 \mathrm{e}-08)$ & $(1.95 \mathrm{e}-08)$ & $(2.67 \mathrm{e}-08)$ \\
TFR & $0.774^{* * *}$ & $1.026^{* * *}$ & $0.702^{* * *}$ & $1.402^{* * *}$ & $1.028^{* * *}$ \\
& $(0.0463)$ & $(0.181)$ & $(0.185)$ & $(0.255)$ & $(0.243)$ \\
IDG & $-0.00258^{*}$ & -0.00310 & -0.00330 & 0.00117 & -0.00749 \\
& $(0.00152)$ & $(0.00539)$ & $(0.00564)$ & $(0.00757)$ & $(0.00688)$ \\
CPR & -0.000323 & 0.00197 & $0.0191^{* * *}$ & 0.00271 & -0.00644 \\
& $(0.00124)$ & $(0.00490)$ & $(0.00500)$ & $(0.00685)$ & $(0.00633)$ \\
Threshold 1 & 0.282 & 0.938 & 1.515 & 2.768 & 1.095 \\
& $(0.202)$ & $(0.708)$ & $(0.730)$ & $(1.001)$ & $(0.990)$ \\
Threshold 2 & 1.282 & 1.946 & 2.587 & 3.768 & 2.086 \\
& $(0.202)$ & $(0.708)$ & $(0.731)$ & $(1.001)$ & $(0.990)$ \\
var (_cons) & & 0.040 & 0.034 & 0.075 & 0.058 \\
& & $(0.011)$ & $(0.011)$ & $(0.021)$ & $(0.017)$ \\
\hline
\end{tabular}

Standard errors in brackets

${ }^{* * *} p<0.01,{ }^{* *} p<0.05,{ }^{*} p<0.1$

Source: SUSENAS 2017 (Authors' compilation).

of PKH acceptance status indicates that after controlling for individual demographic, social, economic, and contextual factors, women who come from households that have received $\mathrm{PKH}$ or currently receive PKH cannot show cards or those from households that have received PKH. Currently receiving PKH and being able to show that PKH cards are more likely to have high fertility intentions (than have no fertility intentions or have low fertility intentions) than women who come from households that have never received $\mathrm{PKH}$.

In model III, the group of women who have had 1 child, after controlling for individual demographic, social, economic, and contextual factors, PKH acceptance status does not significantly affect fertility intentions. Meanwhile, in the group of women with 2 children, after controlling for individual demographic, social, economic, and contextual factors, PKH acceptance status significantly affected women's fertility intentions. Women who have had 2 children and come from households that have received $\mathrm{PKH}$ or are currently receiving $\mathrm{PKH}$ but cannot show a card tend 1, 35 times more likely to have a high fertility intention (than to have no fertility intention or to have a low fertility intention) compared to women who have had 2 children and come from households that have never received PKH. Furthermore, women who have had 2 children and come from households currently receiving $\mathrm{PKH}$ and can show a card are 1.36 times more likely to have a high fertility intention (than have no fertility intention or have a low fertility intention) compared to women who already have 2 children and come from households that have never received $\mathrm{PKH}$. In the group of women who have had at least 3 children, after controlling for individual demographic, social, economic, and contextual factors, PKH admission status significantly affects women's fertility intentions in the current category of receiving $\mathrm{PKH}$ and can show a card. This means that women who have had at least 3 children and come from households currently receiving PKH and can show a card have a tendency of 1.13 times 
higher to have high fertility intentions (rather than having no fertility intention or having low fertility intention) than with women who have had at least 3 children and come from households that have never received PKH.

Contextual factors have a significant relationship with the fertility intention of currently married women aged 15-49 years. The provincial TFR variable has a significant and positive relationship. This means that women living in regions/provinces with a higher TFR are more likely to have a high fertility intention (than have a low fertility intention or do not have a fertility intention) than women living in a region/province with a lower TFR. The provincial IDG variable does not have a statistically significant relationship to women's fertility intentions. This indicates that women's status, position, and role do not influence women's behavior to intend to have children. Meanwhile, the provincial CPR variable has a significant and positive relationship to the women with 1 child group. In other words, women who have had 1 child and live in regions/provinces with higher CPR are more likely to have high fertility intentions (than have low fertility intentions or do not have fertility intentions) than women living in regions/provinces with lower CPR. This indicates that the high level of contraceptive use in a region is not strong enough to influence women who already have 1 child to intend not to have another child. Women who already have 1 child have a high fertility intention because they still want a second child. Thus, if viewed according to contextual factors, a woman's intention to have children is more influenced by the average number of children born to women in an area rather than by the status or position of women and the availability of family planning devices.

\section{Discussion}

Using ordinal and multilevel ordinal regression models, estimation results show consistent results. After being grouped according to women's parity, $\mathrm{PKH}$ acceptance status has a significant positive effect on the fertility intention of currently married women aged 15-49 years. Besides, the results also show at least 3 important things. First, there is an unwanted effect of $\mathrm{PKH}$ assistance on the fertility of the beneficiaries, especially in this case, fertility behavior. Second, women who come from households that have received $\mathrm{PKH}$ or who are currently receiving PKH but cannot show their cards or who currently receive $\mathrm{PKH}$ and can show the cards have a tendency or preference to increase their children (quantity of children). Third, having received $\mathrm{PKH}$ or currently receiving $\mathrm{PKH}$ on fertility intentions is higher than the effect of currently receiving $\mathrm{PKH}$ and can show cards, especially in groups of 1 child and 2 children.

This finding confirms the results of the research by Stecklov et al (2007) and Bastanta (2017), which shows that the conditional cash transfer program is proven to increase fertility due to the tendency of parents to maximize assistance by increasing the number of children rather than improving the quality of children (moral hazard). The occurrence of moral hazard to maximize assistance is closely related to preferences for the number of children and the value of assistance received (Stecklov et al, 2007). As described in the previous section, before 2017, the PKH assistance scheme did not limit the number of family members in calculating the assistance to be received. Thus, there is a tendency for households to maximize assistance with the desire to increase the number of children.

The tendency of women from households that receive $\mathrm{PKH}$ to maximize assistance intending to increase the number of children rather than improve the quality of children is because the assistance received depends on the number of children they have. Moral hazard behavior is more conspicuous among women from households that have received PKH or 
who currently receive PKH but cannot show their cards. Households that had received PKH or could not show a card indicated that they were not disciplined during the $\mathrm{PKH}$ program. The sanction is to be excluded from participating in the $\mathrm{PKH}$ program and reducing the assistance (Kemensos, 2019; Utomo, Hakim, \& Ribawanto, 2014). This undisciplined behavior is related to the seriousness of being a participant in maximizing assistance to improve the quality of children.

Variable area of residence (urban) negatively influences women's fertility intentions. This means that women living in urban areas have a higher tendency to intend not to have children than to intend to have children within more than 2 years compared to currently married women living in rural areas. Women who live in urban areas are more likely not to want to have children (Adhikari, 2010; Ewemooje, Biney, \& Amoateng, 2020) because women's opportunity costs to raise children are higher than women's opportunity costs in rural areas. The more expensive social and economic life in urban areas ultimately chooses of raising children or taking care of large numbers of households undesirable. In addition, the high intention of women living in the village to have children cannot be separated from the strong influence of the social norms "banyak anak banyak rejeki" and "lucky chickens for their feet, good luck for humans on their children," especially for families living in villages (Anjani, Hairunnisa, \& Khoirunisa, 2019; Fahmi \& Pinem, 2018).

Married women with secondary or higher education have a higher intention to have children than married women with low education. Women with higher education are more likely to marry at an older age, reflecting the trade-off between a career or investment in human capital and motherhood (Gustafsson, 2001). This finding is also in line with the research from (Heiland, Prskawetz, \& Sanderson, 2008), which showed that more educated German women have a higher tendency to have children they have a higher level of self-confidence, the ability to cope with stress and pressure from the family and the ability to carry out the role of mother. The other mechanism is because women with higher education are more likely to have husbands who are highly educated (Testa, 2014) who support gender equality in the home, such as contributing to help with housework and child care, to encourage the desire to have more children (Cheng \& Hsu, 2020; Mills, Mencarini, Tanturri, \& Begall, 2008).

\section{Conclusion}

The PKH program is the government's primary strategy to eradicate poverty by increasing the human capital of the poor in Indonesia. However, the PKH program had an undesirable effect on the fertility of poor households because the assistance was a function of the number of children.

The estimation results using ordinal logit regression and multilevel ordinal regression models show that women from households that statistically the conditional cash transfer acceptance status had a significant influence on fertility intentions of married women ages 15-49 years who did not use contraception in Indonesia. Married women ages 15-49 years who did not use contraception, which had or currently received $\mathrm{PKH}$ tended to have higher fertility intentions than to have no fertility intention compared to women from households that have never received PKH even after controlling for the effects of demographic, social, and economic variables and contextual factors according to the parity group.

However, there are unwanted effects, especially in terms of the fertility behavior of PKH beneficiary households. There is a strong tendency for women from households that have received $\mathrm{PKH}$ assistance or are currently receiving $\mathrm{PKH}$ assistance to maximize the assistance received by increasing the number 
of children or a preference for increasing the number of children (moral hazard behavior). Also, moral hazard behavior is more conspicuous among women from households that have received PKH or who currently receive $\mathrm{PKH}$ but cannot show their cards.

Based on the results and conclusions of the study, several policy suggestions can be given, including:

- The maximum number of children counted in the PKH assistance scheme is 2 . This is intended, first, so households receiving PKH assistance are more likely to have only 2 children so they can maximize assistance to increase children's human capital. Second, so it is in line with the appeal of the family planning (KB) program, namely "2 children are better".

- Families who have received PKH should not be re-entered as $\mathrm{PKH}$ recipients because there is a higher tendency for a moral hazard behavior to occur. Also, there need to be strict sanctions for reduced assistance for $\mathrm{PKH}$ recipients who cannot show their cards.

- The results summarize the fertility behavior of currently married women from $\mathrm{PKH}$ recipient households. However, due to limited data sources, this study uses data from the 2017 SUSENAS not intended to specifically evaluate the implementation of PKH, so this study could not analyze the fertility behavior of married women who directly enjoy the benefits of the PKH program. A data source that specifically evaluates the $\mathrm{PKH}$ program is required to achieve these objectives. However, a survey specifically aimed at evaluating the $\mathrm{PKH}$ program, namely the SPKP (Health and Education Service Survey) sponsored by the World Bank and TNP2K, did not provide information on the fertility intentions of beneficiaries.

- This study still uses cross-section data, namely SUSENAS 2017. As a result, this study only concludes that fertility behavior only varies by age group. Ideally, fertility behavior can also vary according to cohort/ generation. In other words, it is necessary to carry out further research that can specifically examine the effects of poverty alleviation programs on fertility behavior according to women cohort groups. In this regard, a data source with a minimum of 15 years is required.

- Ideally, fertility intentions are determined by three main factors: attitudes, subjective norms, and perceived behavioral control. However, due to limited data, this study uses several demographic variables, individual socio-economic and contextual factors, which in the theoretical framework are called background factors. This study can also explain the mechanism of contextual factors in influencing women's fertility intention through the main factor of subjective norms. Thus, it is hoped that the mechanism of contextual factors influences fertility intention through attitudes and perceived behavioral control in future studies.

\section{References}

Adhikari, R. (2010). Demographic, SocioEconomic, and Cultural Factors Affecting Fertility Differentials In Nepal. BMC Pregnancy and Childbirth, 10, 1-11. https:// doi.org/10.1186/1471-2393-10-19

Ajzen, I., \& Klobas, J. (2013). Fertility Intentions: An Approach Based on The Theory of Planned Behavior. Demographic Research, 29(8), 203-232. https://doi.org/10.4054/ demres.2013.29.8

Anjani, R., Hairunnisa, \& Khoirunisa, A. R. (2019). Kampung Keluarga Berencana Sebagai Upaya Mengubah Paradigma Mitos Banyak Anak Banyak Rezeki. Seminar Nasional Bahasa Dan Sastra Indonesia Sasindo Unpam, 1(2), 141-146. Retrieved from https://jurnal.umj. 
ac.id/index.php/SAMASTA/article/ view/7226/4454

Arceneaux, K., \& Nickerson, D. W. (2009). Modeling Certainty with Clustered Data: A Comparison of Methods. Political Analysis, 17(2), 177-190. https://doi. org/10.1093/pan/mpp004

Arroyo, C. R., \& Zhang, J. (1997). Dynamic microeconomic models of fertility choice: A survey. Journal of Population Economics, 10(1), 23-65. https://doi.org/10.1007/ s001480050030

Badan Pusat Statistik. (2018). Indonesia - Survei Sosial Ekonomi Nasional 2017 Maret ( KOR ). Jakarta.

Bastanta, Z. (2017). Evaluasi Dampak Program Bantuan Tunai Bersyarat Terhadap Fertilitas: Kasus Program Keluarga Harapan (PKH) di Indonesia. Universitas Indonesia.

Bourguignon, F., Ferreira, F. H. G., \& Leite, P. G. (2003). Conditional Cash Transfers, Schooling, and Child Labor: MicroSimulating Brazil's Bolsa Escola Program. World Bank Economic Review, 17(2), 229254. https://doi.org/10.1093/wber/lhg018

Chauvet, G. (2015). Coupling methods for multistage sampling. Annals of Statistics, 43(6), 2484-2506. https://doi. org/10.1214/15-AOS1348

Cheng, Y. hsin A., \& Hsu, C. H. (2020). No More Babies without Help for Whom? Education, Division of Labor, and Fertility Intentions. Journal of Marriage and Family, 82(4), 1270-1285. https://doi.org/10.1111/ jomf.12672

Dewey, K. G., \& Begum, K. (2011). Long-Term Consequences of Stunting in Early Life. Maternal and Child Nutrition, 7(SUPPL. 3), 5-18. https://doi.org/10.1111/j.17408709.2011.00349.x

Ewemooje, O. S., Biney, E., \& Amoateng, A. Y. (2020). Determinants of Fertility Intentions Among Women of Reproductive Age in South Africa: Evidence From The
2016 Demographic and Health Survey. Journal of Population Research. https://doi. org/10.1007/s12546-020-09246-w

Fahmi, S., \& Pinem, M. (2018). Analisis Nilai Anak dalam Gerakan Keluarga Berencana bagi Keluarga Melayu. Jupiis: Jurnal Pendidikan Ilmu-Ilmu Sosial, 10(1), 112. https://doi.org/10.24114/jupiis.v10i1.9653

Fiszbein, A., Schady, N., Ferreira, F. H. G., Grosh, M., Keleher, N., Olinto, P., \& Skoufias, E. (2009). Conditional Cash Transfers. In Conditional Cash Transfers. https://doi.org/10.1596/978-0-8213-7352-1 Garganta, S., Gasparini, L., Marchionni, M., \& Tappatá, M. (2017). The Effect of Cash Transfers on Fertility: Evidence from Argentina. Population Research and Policy Review, 36(1), 1-24. https://doi. org/10.1007/s11113-016-9417-x

Gulematova, M. (2011). Evaluating The Impact of Conditional Cash Transfer Programs on Adolescent Decisions About Marriage and Fertility: The Case of Oportunidades (Vol. 25). https://doi.org/10.1007/s00148010-0337-5

Gustafsson, S. (2001). Optimal Age at Motherhood. Theoretical and Empirical Considerations on Postponement of Maternity in Europe. Journal of Population Economics, 14(2), 225-247. https://doi. org/10.1007/s001480000051

Handa, S., Halpern, C. T., Pettifor, A., \& Thirumurthy, H. (2014). The Government of Kenya's Cash Transfer Program Reduces The Risk of Sexual Debut Among Young People Age 15-25. PLoS ONE, 9(1). https:// doi.org/10.1371/journal.pone.0085473

Handa, S., Peterman, A., Huang, C., Halpern, C., Pettifor, A., \& Thirumurthy, H. (2015). Impact of The Kenya Cash Transfer For Orphans and Vulnerable Children on Early Pregnancy and Marriage of Adolescent Girls. Soc Sci Med., 141, 36-45. https://doi.org/doi:10.1016/j. socscimed.2015.07.024 
Heck, R. H., Thomas, S. L., \& Tabata, L. N. (2010). Multilevel and Longitudinal Modeling With IBM SPSS. New York, NY: Routledge.

Heiland, F., Prskawetz, A., \& Sanderson, W. C. (2008). Are Individual's Desired Family Sizes Stable? Evidence From West German Panel Data. European Journal of Population, 24(2), 129-156. https://doi. org/10.1007/s10680-008-9162-x

Hosmer, D. W., \& Lemeshow, S. (2000). Applied Logistic Regression Second Edition. In Applied Logistic Regression. https://doi. org/10.1002/0471722146

Hox, J. J. (2010). Multilevel Analysis. Techniques and Applications (Second Edi). https:// doi.org/10.4028/www.scientific.net/ AMM.556-562.5968

Huang, F. L. (2016). Alternatives to Multilevel Modeling for the Analysis of Clustered Data. Journal of Experimental Education, 84(1), 175-196. https://doi.org/10.1080/00 220973.2014.952397

Kemensos. (2019). Pedoman Pelaksanaan PKH Tahun 2019. Jakarta: Kementerian Sosial Republik Indonesia.

Kementerian Sosial. Peraturan Menteri Sosial Nomor 12018 Tentang Program Keluarga Harapan., Pub. L. No. 1 Tahun 2018 (2018).

Leroy, J. L., Ruel, M., Habicht, J. P., \& Frongillo, E. A. (2014). Linear Growth Deficit Continues To Accumulate Beyond The First 1000 Days in Low and Middle-Income Countries: Global Evidence From 51 National Surveys. Journal of Nutrition, 144(9), 1460-1466. https://doi.org/10.3945/jn.114.191981

Malthus, T. (1798). An Essay on the Principle of Population. London: St. Paul's ChurchYard.

Marquart-Pyatt, S. T. (2012). Contextual Influences on Environmental Concerns Cross-Nationally: A Multilevel Investigation. Social Science Research, 41(5), 1085-1099. https://doi.org/10.1016/j. ssresearch.2012.04.003
McGuire, C., \& Stephenson, R. (2015). Community Factors Influencing Birth Spacing among Married Women in Uganda and Zimbabwe. African Journal of Reproductive Health, 19(1), 14-24.

Mills, M., Mencarini, L., Tanturri, M. L., \& Begall, K. (2008). Gender Equity and Fertility Intentions in Italy and the Netherlands. Demographic Research, 18. https://doi.org/10.4054/demres.2008.18.1

Musca, S. C., Kamiejski, R., Nugier, A., Méot, A., Er-Rafiy, A., \& Brauer, M. (2011). Data with Hierarchical Structure: Impact of Intraclass Correlation and Sample Size on Type-I Error. Frontiers in Psychology, 2(APR), 1-6. https://doi.org/10.3389/ fpsyg.2011.00074

Nandi, A., \& Laxminarayan, R. (2016). The Unintended Effects of Cash Transfers on Fertility: Evidence from the Safe Motherhood Scheme in India. Journal of Population Economics, 29(2), 457-491. https://doi.org/10.1007/s00148-015-0576-6

Phan, L. (2013). Women's Empowerment and Fertility Changes. International Journal of Sociology of the Family, 39(1), 49-75.

Rosenberg, M., Pettifor, A., Nguyen, N., Westreich, D., Bor, J., Bärnighausen, T., Kahn, K. (2015). Relationship between Receipt of a Social Protection Grant for a Child and Second Pregnancy Rates among South African Women: A Cohort Study. PLoS ONE, 10(9), 1-12. https://doi. org/10.1371/journal.pone.0137352

Snijders, T., \& Bosker, R. (1999). Multilevel Analysis: An Introduction to Basic and Advanced Multilevel Modeling. London: SAGE Publications.

Stecklov, G., Winters, P., Todd, J., \& Regalia, F. (2007). Unintended Effects of Poverty Programmes on Childbearing in Less Developed Countries: Experimental Evidence from Latin America. Population Studies, 61(2), 125-140. https://doi. org/10.1080/00324720701300396 
Testa, M. R. (2014). On The Positive Correlation between Education and Fertility Intentions in Europe: Individual- And Country-Level Evidence. Advances in Life Course Research, 21, 28-42. https://doi. org/10.1016/j.alcr.2014.01.005

Todd, J. E., Winters, P., \& Stecklov, G. (2012). Evaluating the Impact of Conditional Cash Transfer Programs on Fertility: The Case of the Red De Protección Social in Nicaragua. Journal of Population Economics, 25(1), 267-290. https://doi.org/10.1007/ s00148-010-0337-5
Utomo, D., Hakim, A., \& Ribawanto, H. (2014). Pelaksanaan Program Keluarga Harapan Dalam Meningkatkan Kualitas Hidup Rumah Tangga Miskin (Studi pada Unit Pelaksana Program Keluarga Harapan Kecamatan Purwosari, Kabupaten Kediri). Jurnal Administrasi Publik, 2(1), 29-34.

Whittemore, A. S. (1997). Multistage sampling designs and estimating equations. Journal of the Royal Statistical Society. Series B: Statistical Methodology, 59(3), 589-602. https://doi.org/10.1111/1467-9868.00084 